Eskişehir Osmangazi Üniversitesi iißBF Dergisi

Ağustos 2020, C. 15, S. 2, $793-810$.

Başvuru : 25.03.2019

Kabul : 06.03.2020

\title{
Darülaceze'nin Kuruluş Gelir Giderleri Üzerine Bir Değerlendirme
}

Büşra Karataşer ${ }^{1}$

Darülaceze'nin Kuruluş Gelir Giderleri Üzerine Bir De-
ğerlendirme
Öz

19. yüzyılda dünya genelinde siyasi, askeri ve kültürel değişmeler yaşanmıştır. Osmanlılar bu düzen değişikliğine ayak uydurmuş ve toplumda zaten süre gelen sosyal yardım uygulamaları hızlanmıştır. II. Abdülhamid döneminde modernleşme faaliyetleri sosyal yardım alanında da kendisini göstermiştir. Bu makale bir sosyal yardım kuruluşu olan Darülaceze'nin kuruluş gelir giderleri üzerine eğilecektir. Klasik Osmanlı yardım kurumlarından farklı olarak tesis edilmiş olan bu yardım kuruluşunu, modernleşme/yenileşme bağlamında bir zemine oturtmak gerekir. Modern anlamda bir sosyal yardımlaşma kurumu olarak Sultan II. Abdülhamid döneminde kurulan Darülaceze, sosyal ve standart bir seviye yakalama amacıyla ortaya çıkmış görünmektedir. Osmanlı Devleti, sosyal yardım konusunu da modern devletin gereği olarak daha standart bir hale getirtmek istemekteydi. Bundan hareketle oluşturulan Darülaceze'nin kuruluşunda hangi kişi veya kurumlar tarafından finansal destek sağlandığı, bu desteklerin sebepleri, kurumun hangi alanlarda giderlerinin olduğunu inceleyeceğiz. Bu makale ile Darülaceze gibi önemli bir kurumun kısa sürede hayata geçmesinin altındaki nedenlere böylece ulaşmak hedeflenmiştir.

Anahtar Kelimeler: 19. Yüzyıl, II. Abdülhamid, Darülaceze, Sosyal Güvenlik, Sosyal Bakım.

\section{An Evaluation on the Organization Income and Expenses of Darülaceze}

\section{Abstract}

In the 19th century, political, military and cultural changes took place worldwide. The Ottoman stept up with this change of order and the social assistance applications that were already in progress in the society have accelerated. In the period of Abdulhamid II, modernization activities also showed itself in the field of social assistance. This article will focus on the establishment in come expenses of Darülaceze, a social assistance institution. This assistance institution, which was established differently from the classical Ottoman assistance institutions, should be placed on a ground in the context of modernization / innovation. Darülaceze, founded in the period of Sultan Abdülhamid II as a social assistance institution in a modern sense, appears to have emerged with the aim of achieving a social and Standard level. The Ottoman State wanted to make the issue of social assistance more standardized as a requirement of the modern state. Based on this, we will examine which individuals or institutions provided financial support in the establishment of Darülaceze, the reasons of these supports and in what fields the institution has expenses. With this article, it is aimed to reach the reasons behind the implementation of an important institution such as Darülaceze in a short time.

Keywords: 19th century, Abdulhamid II, Darülaceze, Social Security, Social Care.

\section{Giriş}

Osmanlı Devleti'nde sosyal hizmetler 19. yüzyıla kadar vakıflar eli ile yürütülüyordu. İslam dünyasında ilk vakfın 625 yılında $\mathrm{Hz}$. Muhammed tarafından kurulduğu kabul edilmektedir. Vakıf sistemi ülkenin eğitim, sağlık ve sosyal yardım, diyanet ve bayındırlık yatırımlarını yürüten kurum olarak mâlî sistemin üçüncü alt öğesidir ve sosyal güvenliğin temel kurumudur. Vakıflar İslâm'daki sosyal hizmet kurumlarının temelini teşkil etmektedir. İslâm devletlerinde, bu arada, Selçuklular ve Osmanlılarda lüks tüketime yönelemeyen tüketici rantları vakıflara yönelerek sosyal refahı yükselten yaygın bir sâbit sermaye teşekkül etmiştir. Vakfın esası bir malı, Allah'ın mülkü hükmünde olmak üzere, ferdî mülkiyet sahasından çıkarmak ve insanların faydalanmasına sunmaktır. Bu da bazı hizmetlerin finanse edilmesi demektir (Tabakoğlu, 2016:136). Hz. Peygamber, hayrî vakıflarından başka, sahibi olduğu arazilerini i̇slâm

\footnotetext{
${ }^{1}$ Dr. Öğretim Üyesi Büşra Karataşer, Tekirdağ Namık Kemal Üniversitesi İktisat Bölümü, bkarataser@nku.edu.tr, Yazar ORCID bilgisi: http://orcid.org/0000-0002-3208-657X.
} 
toplumunun ihtiyaçlarına, ordunun teçhizine ve Müslümanların fakirlerinin ihtiyaçlarının karşılanmasına tahsis etmek suretiyle vakıf hizmetlerinin ilk örneklerini ortaya koyarak ashabına örnek olmuştur(Turgut,2018:4).

“Abdullah b. Ömer'den rivayet olunduğuna göre, babası Hz. Ömer (r.a.), Rasulullah (s.a.v.) zamanında "Semğ" denilen öz malı hurmalığı vakfetmek isteyerek: Ya Rasulullah! Çok güzel ve kıymetli bir hurmalığa sahip bulunuyorum. Bu malımı vakfetmek istiyorum, bana ne tavsiye edersiniz? diyerek Hz. Peygamber'e başvurdu. Bunun üzerine Nebi (s.a.v.): Bu hurmalığın aslını (rakabesini) vakfet! Artık o satılmaz, hibe edilmez, vâris olunmaz, yalnız onun ürünü infak edilir, buyurdu. Ömer de bu malını o suretle vakfetti. Gelirini, Allah yolunda savaşanlara, azatık anlaşması yapmış kölelere, miskinlere, misafirlere, yolculara ve yakın akrabalarına vakfetti (Wensick, 1936).

İslâm iktisat sisteminin temel supabı zekâttır bu sayede gelirlerin bir kaynakta toplanması engellenmiş olur. Zekât sistemin koruyucusudur. Zekât, servet ve mülkiyetin yaygınlaştııılmasını, gelirin bir nesil içerisinde yeniden dağılımını sağlayarak gerçekleştirir. Zekât esas olarak servetleri belirli bir seviyenin (nisâbın) üzerinde olanlardan bu seviyenin altında olanlara bir gelir aktarmasını öngörür. Gelir aktarmasının çalışan ve çalışmayan iki küme meydana getirmesi yeterli gelir sağlamaya gücü yetenlerin bu aktarmaların dışında bırakılmasıyla önlenir. Zekat sayesinde yoksul durumda olanlara yardıma intiyaç duyulan insanlara kaynak sağlanmış olur (Tabakoğlu, 2013:38).

19. yüzyıl dünyada istikrarsız bir dönem olmuştur. Yaşanan savaşlar, ülkelerde başlayan milliyetçilik hareketleri sebebi ile yaşanan göçler dünyada milletlerden oluşan devletler oluşumuna sebep olmuştur. Göç eden kesim hasta, yaşlı muhtaç durumda olanlardır. Bu sebeple toplumda dilencilik artmış, Osmanlı Devleti'nde basına da yansıyan sorunlar oluşmuştur. 1877-1878 Osmanlı -Rus savaşı sonrasında ortaya çıkan olumsuz sonuçlar ekonomik ve siyasi bunalımlara sebep olmuştu. Yaşanan savaş sebebiyle Rumeli Bölgesi'nden İstanbul'a önemli bir göç olmuştu. Yaşanan büyük savaş sebebiyle dört yüz bine yakın insanın İstanbul'a göç etmiştir. Göç eden nüfusun önemli bir bölümü ise evsiz, sakat, hasta kimselerden oluşuyordu(Birol, 2017:34).

Osmanlı Devleti'nde dilenciliğin kaynakları yoksulluk, doğuştan ve sonradan meydana gelen sakatlık, özür, istihdam imkânlarını yeterli olmaması, savaşlar ve başka sebeplerle yaşanan göçün getirdiği sıkıntılar, bulundukları bölgelerde kıtlık, susuzluk ve afet gibi sebeplerle geçim sıkıntısı çekilmesi şeklinde ortaya çıkmıştır(Öztürk,2008:110-111).

\section{Kavramsal Çerçeve}

Osmanlı Devleti'nde 19. yüzyıla kadar toplumda sosyal hizmet kurumlarının temelini vakıflar oluşturuyordu. Osmanlı Devleti'nde vakıf sistemi sosyal güvenlikle ilgili olduğu kadar ülkedeki eğitim, sağlık ve sosyal yardım, diyanet, bayındırlık yatırımlarını yürüten kurum olarak Osmanlı mali sisteminin üçüncü alt istemini oluşturmaktadır. Vakıf kurucularının bir kısmı padişah ve vezirlere ait olan büyük vakıflardı. Osmanlı vakıf sistemi özerk ve demokratik bir sivil toplum sistemi olmakla birlikte devletin denetimi dışında değildir. Nezaret kurumu bu denetimi sağlamaktadır. Özellikle büyük vakıflar sadrazam, şeyhülislam, başdefterdar, kadı, Enderun gibi devlet görevlilerinin nezareti altındadır (Tabakoğlu, 2014:307-308)

Osmanlı Devleti 19. yüzyıl ile birlikte modernleşme hareketlerine başlamıştır. Yaşanan savaşlar sebebiyle göç hareketleri artmış ve başkent İstanbul olmak üzere birçok bölgede nüfus hareketi artmıştır. Bu sebeple toplum yapısı değişmiştir. Öksüz, yetim sayısı artmıştır. Yardıma muhtaç durumda olanları himaye etmek amacıyla çeşitli kurumlar açılmıştır. 


\section{Araştırmanın Yöntemi}

Osmanlı Devleti'nde yoksullukla mücadele klasik dönemden itibaren devam etmiştir. Yoksula, ihtiyaç duyana yardım etmek devlet görevleri arasında sayılmıştır. Bu çalışmada Osmanlı İmparatorluğu'nda yoksullar ve yoksullara yönelik yardım politikaları incelenmiştir. Osmanlı toplumunda savaşların sebep olduğu yoksulluk ve dilenciliğin artması sebebi ile dilenciliğin artmasından bahsedilmiştir. Artan dilenci ve yoksul sayısı Osmanlı Devleti'ni Darülaceze açmaya mecbur kılmıştır. Ülkenin ekonomik durumu yeterli olmasa da yoksulu himaye etmek adına kurum oluşturulmasına karar verilmiştir. Darülaceze mali sıkıntılar içinde kurulmuş ve toplumda başta yoksullara sonra ihtiyacı olanlara hizmet etmiştir. Darülaceze gibi bir hayır kurumunun kurulması için toplumun her kesiminden yurt içi yurt dışından yardım gönderilmiştir.

\subsection{Prosedür}

Osmanlı Devleti'nde yoksullukla mücadele yöntemi kurumların tesisi ile sağlanmıştır. Başlangıçta vakıflar ile sağlanan yoksula yardım etme mekanizması zaman içerisinde değişen dünya düzeni ile birlikte yeni kurumlar oluşturulmasına sebep olmuştur.

\subsection{Araştırmanın Bulguları ve Sonuçları}

Osmanlı Devleti'nde yoksullukla mücadele adına açılan kurumlardan en önemlisi Darülaceze'dir. Ülkenin nüfusunun hızla arttığı bir dönemde dilencilik artmış ve toplumsal bir sorun haline gelmiştir. Yaşanan toplumsal sorunlar Osmanlı Devleti'ni yeni kurumlar tesis etme yoluna götürmüştür. Yaşanan savaşlar sebebi ile toplum yapısıyla birlikte ekonomi de kötüleşmiştir. Ancak yoksullara yardım için bir kurum kurulması gerektiği toplumun her kesimi tarafından kabul gördüğünden kurum için toplumdaki herkes para yardımı yapmıştır. Yardımlarda aksama yaşandığı durumlara Nezaretlere yazılar yazılara Darülaceze'nin öneminden bahsedilerek yardımların düzenli yapılması istenmiştir. Bu yazışmalar olumlu sonuçlar vermiş ve Darülaceze kısa süre içerisinde hizmete açılmıştır. Sadece yoksullara hizmet vermek amacıyla kurulsa da zaman içerisinde kadınları ve çocukları da himaye edecek kurumlar açılmıştır. Bu sayede Osmanlı Devleti'nde her zaman var olan yoksula yardım konusu kurumsallaşarak devam etmiştir.

\section{Osmanlı İmparatorluğunda Yoksullar ve Yoksullara Yönelik Yardım Politikaları}

Osmanlı Devleti 19. yüzyıl ile birlikte sosyal hayata birçok alanda etki bırakmıştır. Önceki devirlerdekine nazaran modern teknolojinin gelişmesiyle birlikte yeni bir bürokratik devlet oluşmasına sebep olmuştur (Özbek, 2002:47-48). 19. yüzyılda bu fikrin sıkıntıya girmesi ile birlikte, devletin müdahale alanı genişlerken bir yandan sosyal alan oluştuğunu görmekteyiz. Osmanlı Devleti'nde ihtiyaçların giderilmesi, refahın temini ve toplumun mutluluğunun temin edilmesi konuları devletin gündeminde olmuştur. Toplumun refah ve güvenliğini sağlama olgusu devleti de modern bir devlet haline getirmiştir. Osmanlı Devleti'nde yoksulara yardım ailenin geçimini sağlayamama, sağlık sorunları, gibi durumlarda sağlanıyordu.

19. yüzyıla kadar Osmanlı toplumu dâhilinde sosyal yardım alanında yaşanan yardım faaliyetleri vakıflar ve imaretler şeklinde kendini gösteriyordu. Merkezi devletin güç sahip olması ile birlikte vakıflardan temin edilen gelirler maliye hazinesi dâhil edilerek bu kurumlar kaynaksız bırakılmıştır. O döneme kadar işler durumda olan vakıflar üç ana grupta toplanmaktaydı. Bunlar Osmanlılardan önceki İslam devletlerinden intikal eden evkaf-ı kadime, miri arazinin temliki suretiyle kurulan evkaf-ı irsadiyye ve hayırsever kimseler tarafından kendi mülklerinden ayırdıkları mallarla tesis ettikleri evkaf-ı sahiha-i lazime idi (Tabakoğlu-Karataşer, 2019:435). Evkaf-ı Hümayun Nezareti 1826 yılında kurulmuş olup, vakıf yapılarının tamirinde ve finansmanında önemli sorumluluk üstlenmiştir (Öztürk,2019:116). 
Osmanlı Devleti sosyal yardım faaliyeti olarak muhtacın maaşı adı verilen yardıma muhtaç insanlara düzenli bir gelir sağlama yoluna gitmiştir. Yine aynı şekilde Tanzimat döneminde ise maliye bütçesinden yapılan tahsisatlar dışında taşrada vali yetkisi dâhilinde bulunan Kapualtı hasılatı adı verilen fukaraya yardım amacı ile harcama yapıldığı görülmektedir (Özbek,2002:4755).

Tanzimat'ın ilanında etkin rol oynayan düşünceler yapılan ıslahatların ordu ile başlayıp diğer alanlara da sirayet edeceği düşünülmüştür. II. Abdülhamid'in tahta çıkması ile birlikte modern ve geleneksel uygulamalar birlikte Osmanlı imparatorluğu modernleştirilmeye çalışılmıştır. Avrupa'da yaşanan modernleşme hareketleri yakın bir şekilde takip edilerek sosyal devlet kavramı Osmanlı ülkesi dâhilinde oluşturulmak istenmiştir. Dünyada artan zenginlikten sadece zengin kesim yaralanırken fakir kesimin daha da kötü ve zor koşullarda yaşadığı görülüyordu (Akyol, 2013:35).

II. Abdülhamid döneminde sosyal yardım ve politika konusunda önemli adımlar atılmıştır. Sağır ve dilsizler için açılan okullar, iş kazası mağdurları için oluşturulan sigorta fonu Osmanlı Devleti dâhilinde yaşayanlar için sosyal yardım sistemi oluşturulmaya çalışılmıştır. II. Abdülhamid'in amacı devlet tarafından sosyal refah programlarının gerçekleştirilerek modern topluma dönüşümü sağlamaktı. II. Abdülhamid döneminde sosyal yardım anlamında ilk uygulama Atiyye-i seniyyedir (Akyol, 2013:35-40). Atiyye-i Seniyye, ihtiyacı olan halka para yardımı bulunmaktır. Osmanlı bütçelerinde Atiyye-i Seniyye için bir ödenek ayrılmıştı. Tanzimat döneminden önce Atiyye-i Seniyye harcamaları çoğunlukla padişahların özel hesapları tarafından Ceyb-i Hümayundan yapılıyordu daha sonra ise Tahsisat-ı Seniyye adı verilen padişah ve saray için ayrılmış olan ödenekten karşılanıyordu (Özbek,2002:125-126

\section{Osmanlı Toplumunda Savaşların Sebep Olduğu Sosyal Yapıda Bozulma: Dilenciler ve Di- lencilere Yönelik Yaklaşımlar}

19. yüzyılın sonu siyasi ve iktisadi açıdan istikralı bir dönem değildir. II. Abdülhamid' in saltanatının ilk yıllarında karşılaştığı en önemli problem Balkanlar'da 1876'da çıkıp aynı yıl bastırılan Bulgar, Sırp, Karadağ isyanlarıdır. Bu isyanlar 1877-1878 Osmanlı-Rus Savaşının sebeplerinden birini oluşturmuştur. Osmanlı Devleti bu savaşta ağır bir yenilgi alarak Ruslarla Edirne Mütarekesini ardından da Ayastefanos Antlaşmasını imzalamak zorunda kamıştır. Osmanlı Devleti'nin hudutları daralmış savaş sonrası elden çıkan toprak miktarı $287.510 \mathrm{~km}^{2 \prime}$ dir. Ülke topraklarının küçülmesiyle birlikte devlet gelir ve giderlerinde azalma görülmüştür. Anadolu nüfusunda 1878-1883 döneminde önemli bir nüfus değişimi yaşanmıştır. Osmanlı Rus Savaşının hemen öncesinde 12.500 .000 olduğu tahmin edilen Anadolu nüfusu savaşın getirdiği kayıplar sebebi ile 1884 yılında, bu tarihe kadar gelen bir milyon göçmene rağmen 11.436 .000 'e düşmüştü. 1882 yılına kadar Osmanlı Devleti'ne gelen kayıtlı göçmenlerin sayısı 1.200.000'e ulaşmaktadır. 1884 'teki rakamlara göre ülke nüfusu 28,9 milyon Anadolu nüfusu ise 11,8 milyon tahmin edilmekteydi (Tabakoğlu,2011:211-218). Yaşanan bütün gelişmeler nüfusun artması, ülkenin mali durumunun iyi olmaması, savaşlar toplumda güçsüz, yardıma muhtaç insan sayısını artırmıştır. Bu sebeple muhtaç, kimsesiz insan sayısı artmıştır. Muhtaç insanları himaye edecek kurumlara ihtiyaç duyulmuştur.

Osmanlı Devleti'nde zaman içerisinde gerçekten yardıma ihtiyacı olan yoksulla, yardımı hak etmeyen kesimler arasında bir ayrım yapılmıştır. Osmanlı klasik döneminde bir ayrım yapılmış ve kent merkezinde dilenciler kontrol edilmiştir. Çalışamayacak durumda olanlara bir tür sertifika verilirken çalışabilecek durumda olanlara ise çeşitli şekillerde cezalandırılmıştır. 


\section{Darülaceze'nin Kurulması}

Darülaceze, toplum içinde kimsesiz, muhtaç durumda olanları himaye etmek üzere kurulmuştur (Öztürk, 2008:117). Darülaceze Nizamnamesinin birinci maddesine göre Darülaceze doğrudan Dâhiliye Nezaretine bağlı olarak ve müstakil bir bütçesi olarak kurulmuştur. Darülaceze zükur, İnas, çocuklar şubesi, Irza'hane olmak üzere dört bölümden oluşuyordu. Darülaceze'ye ancak Dersaadet'te doğan veya yerleşmiş olup ya da iş yapamaz ve geçinmeye yetecek malı olmayanlar, çalışmaya gücü olmayan güçsüz ve aciz durumda olanlar kabul edilecektir (Düstur, 1.tertip,1895:43-48).

Ayrıca sokaklardan artan dilenciliği önlemek amacı ile 29 Ocak 1896 tarihinde dilenciliğin men edilmesine dair bir nizamname yayınlanmıştır. Bu nizamname II. Meşrutiyetin ilanını takiben toplumda asayiş ve toplumsal düzende bozulmalar yaşanmış dolandırıcılık, hırsızlık, soygunculuk gibi olaylar artma eğilimi göstermiştir. Bu istenmeyen sebeplere taşradan gelenlerin sebebiyet verdiği ağırlık kazanınca Serseri Nizamnamesi yürürlüğe girmiştir (Öztürk,2008:116) Bu Nizamnamenin dokuzuncu maddesine göre çalışmaya gücü olup çalışamayanlar serseri olarak kabul edilmiştir. Çalışmaya muktedir olduğu çalışmayanlar zabıta tarafından tutuklanarak bunlardan İstanbullu olanlar veya taşralı olup ta İstanbul'a yerleşenler zabıta tarafından kefaletle serbest bırakılacaklardır. Taşra ahalisinden olanlar ise memleketlerine gönderileceklerdir. Birden fazla defa dilencilikten yakalanan İstanbullu olan olursa taşraya gönderilecektir(Düstur, 1895:49).Darülaceze'nin kurucusu Sultan II. Abdülhamid Han'dır.30 Mart 1890 tarihinde yayınlanan bir irade ile sokaklarda dilenen kimsesiz çocuklar, sakat erkek ve kadınlar için dilenmeyi engellemek, eğitim ve bakımlarını temin edilecek bir yer ayrılması istenmiştir (Nuhoğlu, 1993:512).

Darülaceze binası 19. yüzyıla ait ihaleler içerisinde sürecin en iyi izlendiği yapılardan biridir. Darülaceze binasının inşaatı Vasilaki isimli saray ve padişah mimarı tarafından üzerine alınmıştır. II. Abdülhamid döneminde saray mimarı ve kalfası Vasilaki ve oğlu İoannidis tersanede faaliyet gösteren Marki kalfanın soyundan gelmektedir. Darülaceze binası Kâğıthane bölgesinde geniş bir alanda Hıristiyanlar için kilise, Yahudiler için sinagog ve Müslüman ahali içinde cami olan bir kurum olacaktı. 7.136.674 kuruş masrafla bu yapının inşa edileceği yapılan keşif sonucunda ortaya çıkmıştır. Bedelin \%10'luk kısmının peşin olarak ödenmesi ve \%20 si içinde kefil göstermesi ihale şartlarında gösterilmiştir(Şenyurt, 2010:542-543).Yapılacak kurumun herhangi bir din ayrımı yapmadan bütün Osmanlı vatandaşlarına hizmet etmesi temel unsuru olmuştur. II. Abdülhamid'in yaptırdığı hayır kurumları içinde özel bir yeri olan Darülaceze bulunduğu dönemde modern bir sosyal kurum olarak görülmektedir. 1892 yılında inşasına başlanmış olup 1895 yılında açılmıştır(Aytekin, 2006:25).

Darülaceze, 18 bina ile hizmete girmişti. Kurumun girişinde memurlar için ayrılan bölümün dışında dörder tane Müslüman aceze ve Hristiyan aceze için bölüm ayrılmıştı. Bu koğuşların altında ise imalathane ve yemekhaneler bulunuyordu. Darülacezenin hizmete girmesi ile birlikte gazeteler kurumdan büyük özgüyle bahsetmektedir. Az zamanda sadece Osmanlı toprakları dâhilinde değil belki de dünyanın hiçbir yerinde benzeri olmayan bir bina inşa edilmişti (Demirel,2011:114-115).

Kurulan kurum, farklı dinlerden Osmanlı vatandaşlarını hem yönetimine dâhil etmiş hem de ayırım yapmadan bütün halkına hizmet amacı ile kurulmuştur(Yazıcı,2007:44).Darülaceze'ye bir nizamname hazırlamak amacı ile yönetim toplanmıştır. Yapılan toplantıda Darülaceze'ye alınacaklar ve şartları ve kurumla ilgili diğer konular görüşülmüştür. Darülaceze'ye alınacak sakinlerin 
İstanbullu olan, taşradan gelip uzun bir süredir İstanbul'da ikamet etmekte olan acezeyi barındıracağı belirtilmiştir (Yıldırım, 1996:24-26).Darülacezede bir Irza'hane, kreş, yetimhane, okul, imalathaneler bulunuyordu. Darülaceze'nin açılmasıyla birlikte dilencilik yasağı yenilendi ve 28 Ocak 1896 tarihinde Darülaceze Nizamnamesi çıkarıldı. Darülaceze'nin kurulması için gerekecek masrafların Selatin Vakıflarından para ayrılması ve ayni yardım sağlanması, fukara için düzenlenecek balo ve konserlerden \%1 Darülaceze hissesi alınması, tiyatro biletlerinden bastırılacak pullarda bir Darülaceze yardımı alınması nizamnameye göre belirtilmişti (Koçu, 1974:35).

\section{Darülaceze'nin Kurulması İçin Mali Kaynaklar}

II. Abdülhamid döneminde birçok hayır kurumu kurulmuştur. Bunların en önemlilerinden birisi de Darülaceze'dir. Bu kurumun bir an önce kurulması için Kurumun inşasının gecikmemesi bir an önce ihtiyaç sahiplerine ulaştırmak amacı ile birçok çaba gösterilmiştir. Darülaceze'nin mali kaynaklarını artırmak amacıyla padişah emriyle vilayet ve mutasarrıfıklara dağıtılmak üzere yardım biletleri gönderilmiştir.

Yardım biletlerinin yanında Darülaceze'nin inşası için özel olarak yardımda bulunmak isteyenlerde Darülaceze'nin kurulmasına katkıda bulunmuşlardır. Yardım biletleri Dâhiliye Nezareti tarafından her ay toplanmakta ve Bank-ı Osmani'ye tahsis edilmekteydi(BOA, A.MKT-MHM 703-1/6-2).

Tablo 1: 1894 Yılı Darülaceze Gelirleri

\begin{tabular}{|c|c|c|c|c|}
\hline \multicolumn{5}{|c|}{1894 Yılı Darülaceze Gelirleri } \\
\hline Aylar & $\begin{array}{l}\text { Merkezi Daireler } \\
\text { (Kuruş) }\end{array}$ & $\begin{array}{l}\text { Vilayet ve Müstakil } \\
\text { livalardan (Kuruş) }\end{array}$ & $\begin{array}{l}\text { Bilet Dışında Yar- } \\
\text { dım (Kuruş) }\end{array}$ & $\begin{array}{c}\text { Bazı kişiler } \\
\text { Tarafından Ayrıca } \\
\text { Yapılan Yardım (Ku- } \\
\text { ruş) }\end{array}$ \\
\hline Ş̧ubat & 427.336 & 938.784 & 937.417 & 169.454 \\
\hline Mart & 80.887 & 91.574 & 21.532 & --- \\
\hline Nisan & 978 & 104.000 & 21.688 & 3.894 \\
\hline Mayıs & 24.686 & 45.751 & 313.500 & 313.500 \\
\hline Haziran & 38.849 & 45.619 & 1.866 & 22.332 \\
\hline Temmuz & 65.888 & 15.705 & 7.375 & 30.842 \\
\hline Ağustos & 26.893 & 7.305 & 1.039 & --- \\
\hline Eylül & 3.974 & 63.726 & --- & 7.500 \\
\hline Ekim & 3.494 & 46.071 & --- & 160.300 \\
\hline Kasım & 1.992 & 10.748 & --- & 1.293 \\
\hline Aralık & 58.597 & 3.071 & --- & 807 \\
\hline TOPLAM & 733.574 & 1.372 .354 & 1.304 .417 & 709.922 \\
\hline 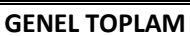 & & & & 4.120.267 \\
\hline
\end{tabular}

1894 yılında toplam gelir 4.120.267 kuruştur. Bu gelirin merkezi dairelerden olan kısmı 733.574 kuruştur. Toplam gelirin içerisinde merkezi dairelerin payı \%17,8'dir. 1894 yılının Şubat ayından Aralık ayı sonuna kadar Darülaceze'nin kuruluş gelirleri arşiv belgelerinden 11 aylık tespit edilmiştir. Genel anlamda bakıldığında bu gelirler dört başlık altında toplanmaktadır. Merkezi Devlet Dairelerinden, Vilayet ve Müstakil livalardan, bilet dışında yardım, bazı kişiler tarafından ayrıca toplanan yardımlardır. Merkezi Daireler'den hemen her ay düzenli olarak bir gelir elde edilmiştir.

1894 yılı Şubat ayında en fazla para Hazine-i Hassa'dan gelmiştir. Genel anlamda incelendiğinde Darülaceze'nin kurulması için ülke genelinde hemen her kurumdan yardım istendiği ve 
bunun düzenli şekilde yapıldığı görülmüştür. Özellikle gönderilen paraların takibi yapılmış ve bu meblağları göndermeyen bakanlıklar tarafından uyarılmıştır. Uyarı sebebi olarak da Darülaceze inşaatının geciktiği bildirilmiştir. Bu kurumun bir hayır kurumu olması sebebi ile gönderilecek yardımların bir an önce gönderilmesi istenmiştir(BOA, A.MKT-MHM 703-1/8-1).

Bazı kişiler tarafından bilet alınmadan yapılan yardımlar ise 1894 yılı Şubat ayı için 169.454 kuruştur. Bu yardımları yapanlar Yunan zenginlerinden, İncesu kaymakamının eşi tarafından, Halep ve Adana Telgraf Müdürü'nün eşi tarafından, Kitapçı Kaspar Efendi tarafından, İtalya cemiyeti tarafından yapılmıştır. Toplumun her kesimi hatta yurtdışından bile yardım yapılmış$\operatorname{tir}($ BOA, A.MKT-MHM 703-1/8-2).

1894 yılı Mart ayında, bazı kişiler tarafından ayrıca yapılan yardımlar ise, Nafia Nazırı Tevfik Paşa tarafından 5.000 kuruş, Anadolu Demiryolu Müdürü tarafından 20.000 kuruş, Baron Roceld tarafından 10.000 kuruş, Selanik Tüccarı Mişon Milon tarafından ise 1000 kuruş yardım yapılmıştır.

1894 yılı Eylül ayında bazı kişiler tarafından yardımlara baktığımızda ise Mudanya Şimendifer Kumpanyası tarafından 2.500 kuruş, Varna Saygınları tarafından 5.000 kuruş toplanmıştır (BOA, A.MKT-MHM 703-1/8-2).

1894 yılı Ekim ayında ise, bazı kişiler tarafından ayrıca gönderilen yardımlara baktığımızda ise, Beyrut Şam ve Bilecik Demiryolu Şirket vekili Mösyö Alfred tarafından 150.000 kuruş, yol Müteahhidi Mehmet Efendi tarafından depozito olarak teslim edilen 10.300 kuruş yardım edilmiştir (BOA, A.MKT-MHM 703-1/8-2).

1894 yılı Kasım ayında ise, bazı kişiler tarafından nakit olarak yapılan yardımlar ise Haçik Efendi'den 1200 kuruş, Paris'te bir düşes tarafından 43 kuruş 37 santim, Karabet Gedikliyan tarafından 50 kuruştur (BOA, A.MKT-MHM 703-1/8-2)

1894 yılı Aralık ayında ise, bazı kişiler tarafından ayrıca yapılan yardımlara baktığımızda ise, Illanat-ı Nizamiye İcra Memuru Vasıf Bey ve eşi tarafından 807 kuruş 50 santim gönderilmiştir (BOA, A.MKT-MHM 703-1/8-2).

Tablo2: 1895 Yılı Darülaceze Gelirleri

\begin{tabular}{|c|c|c|c|c|}
\hline \multicolumn{5}{|c|}{1895 Yılı Darülaceze Gelirleri } \\
\hline Aylar & $\begin{array}{l}\text { Merkezi Daireler } \\
\text { (Kuruş) }\end{array}$ & $\begin{array}{l}\text { Vilayet ve Müstakil li- } \\
\text { valardan (Kuruş) }\end{array}$ & $\begin{array}{l}\text { Bilet Dışında Yar- } \\
\text { dım (Kuruş) }\end{array}$ & $\begin{array}{c}\text { Bazı kişiler Tarafından } \\
\text { Ayrıca Yapılan Yardım } \\
\text { (Kuruş) }\end{array}$ \\
\hline Şubat & 5.822 & 21.402 & --- & 115.473 \\
\hline Mart & --- & --- & --- & --- \\
\hline Nisan & --- & --- & --- & --- \\
\hline Mayıs & --- & 16.968 & --- & 15.000 \\
\hline Haziran & 275 & 3.288 & --- & 30.073 \\
\hline Temmuz & --- & 1.549 & --- & 100.000 \\
\hline Ağustos & 4.196 & 15.889 & --- & 2.187 \\
\hline Eylül & 4.284 & 23.940 & 8.071 & 10.000 \\
\hline Ekim & --- & 50.597 & 1.989 & 79.815 \\
\hline Kasım & --- & --- & --- & --- \\
\hline Aralık & --- & --- & --- & --- \\
\hline TOPLAM & 14.577 & 133.633 & 10.060 & 352.548 \\
\hline GENEL TOPLAM & & & & 510.818 \\
\hline
\end{tabular}

Kaynak: BOA, A.MKT-MHM 703-1/8-2.

1895 yılı gelirleri ise 1894 yılının Şubat ayından 1895 senesinin Nisan ayına kadar üç ay içerisinde yapılan yardımlar şu şekildedir: Merkezi Dairelerden toplanan gelirlere baktı̆̆ımızda 
Posta ve Telgraf Nezareti'nden 2.591 kuruş 50 santim, Defter-i Hakani'den 1.290 kuruş 50 santim, Hariciye Nezareti'nden 572 kuruş, Rüsumat Emaneti'nden 1.368 kuruş 25 santimdir. Vilayet ve Mutasarrıflıklardan gelen yardımlara baktığımızda ise Suriye Vilayeti'nden 1600 kuruş, Selanik Vilayeti'nden 4.044 kuruş 60 santim, Halep Vilayeti'nden 4.313 kuruş, Musul Vilayeti'nden 1.805 kuruş, Manastır Vilayeti'nden 4.313 kuruş, Basra Vilayeti'nden 1.125 kuruş 75 santim, Kosova Vilayeti'nden 758 kuruş, 50 santim, Mamuratülaziz Vilayeti'nden 466 kuruş 50 santim, Zor Sancağı'ndan 2.014 kuruş, İzmit Sancağı Mutasarrıflığı'ndan 560 kuruş 50 santim gönderilmiştir. Bazı kişiler tarafından ayrıca yapılan nakit yardımlar Anadolu Demiryolu İdaresi tarafından 100.000 kuruş, Mimar Yanko Bey tarafından 10.000 kuruş yardım yapılmıştır. Darülaceze'nin kurulması için toplanan yardımlara baktığımızda 1895 yılında ilk üç ayda vilayetlerden düzenli olarak yardım geldiğini görüyoruz. Bir önceki yıla baktığımızda aynı vilayetlerden her ay yardım toplanamazken 1895 yılı içerisinde üç ay arka arkaya yardım toplanan yardımlar yardım toplamanın düzenli hale geldiğini göstermektedir (BOA, A.MKT-MHM 703-1/34-2).

1895 yılı Mayıs ayında ise, bazı kişiler tarafından yapılan yardımlar ise Şam ahalisinden ElBatutum ve İbrahim Nepo Efendiler tarafından 15.000 kuruş gönderilmiştir (BOA, A.MKT-MHM 703-1/34-2). Haziran ayına baktığımızda merkezi dairelerden Posta ve Telgraf Nezareti'nden 275 kuruş yardım gönderilmiştir. Vilayet ve Mutasarrıflıklara baktığımızda Selanik Vilayeti'nden 1908 kuruş 50 santim, Musul Vilayeti'nden 712 kuruş 50 santim, Limni Sancağı Mutasarrıflığı'ndan 648 kuruş 75 santim nakit olarak, 28 kuruş 50 santim sened olarak gönderilmiştir. Bazı kişiler tarafından ayrıca nakit olarak yapılan yardımlar ise şu şekildedir, Sosyete Ottoman de Valor namına 30.000 kuruş, Şirketi Osmaniye Müdürlüğü'nden 73 kuruş gönderilmiştir (BOA, A.MKT-MHM 703-1/34-2). Temmuz ayında ise, bazı kişiler tarafından ayrıca ve nakit olarak verilen yardımlar ise Kasaba demiryolu imtiyaz sahibi Mösyö Nakli Gery tarafından 100.000 kuruş yardım yapılmıştır (BOA, A.MKT-MHM 703-1/40-01). Ağustos ayında yapılan yardımlar ise bazı kişiler tarafından ayrıca yapılan yardımlar ise Mösyö Enso tarafından 200 kuruş, Gümüşsuyu Hastanesi doktorlarından Velkoviç tarafından 1.987 kuruş yardım yapılmıştır (BOA, A.MKTMHM 703-1/42-01.

Aylar itibariyle takip edildiğinde her ay İstanbul'da bulunan resmi dairelerden yardım geldiğini ancak gelen yardımların her ay aynı daireden gelmediğini görüyoruz. 1894 yılı Mayıs ayında, bazı kişiler tarafından ayrıca yapılan yardımlar ise Osmanlı Düyun-u Umumiye Müdürü Mösyö Kont Darson'un kayınpederi Paris Bankerlerinden Mösyö Bardan tarafından 10.000 kuruş yardım yapılmıştır. Fazla biletten yapılan yardım ise Viyana kuyumcularından Edmon Bahican isimli şahıs tarafından 8.071 kuruş yardım yapılmıştır (BOA, A.MKT-MHM 703-1/44-01). Ekim ayında ise İstanbul'da bulunan merkezi dairelerden yardım alınamamıştır. Bazı kişiler tarafından ayrıca yapılan yardımlar ise Paris'te ikamet eden Banker Mösyö Elilion tarafından 10.00 kuruş, Dedeağaç Demiryolu imtiyaz sahibi Mösyö Renebodri tarafından yıllık yardım 2.00 kuruş, kitapçı İrfan Efendi tarafından 755 kuruş, Eskişehirli Mehmet Efendi tarafından 800 kuruş, Üsküdar ve Kadıköy Su Şirketi tarafından 1.000 kuruş, Madam Zafiro Polo adına Mösyö Luindas tarafından, Viyana Bankerlerinden Mösyö Oldaşnayn tarafından 10.000 kuruş, Erkan-ı Harbiye Albay Şerafettin Bey'in Darülaceze yararına bastırmış olduğu kitap gelirinden 926 kuruş 75 santim fazla biletten ise Hariciye Nezareti'nden 1.989 kuruş yardım yapılmıştır (BOA, A.MKT-MHM 703-1/46-01). 1894 ve 1895 yılı gelirleri toplandığında toplam Darülaceze geliri 4.891.762 kuruştur. 


\section{Darülaceze'nin 1894 Yılı Giderleri}

Tablo 3: 1894 Yılı Darülaceze Giderleri (Şubat-Mayıs Ayları) 1894 Senesi Darülaceze Giderleri (Şubat- Mayıs Ayları)

\begin{tabular}{|c|c|c|c|c|}
\hline \multirow[b]{2}{*}{ Gider kalemleri } & \multicolumn{2}{|c|}{$\begin{array}{c}1894 \text { Senesi Şu- } \\
\text { bat ayı sonuna } \\
\text { kadar yapılan } \\
\text { harcamalar }\end{array}$} & \multicolumn{2}{|c|}{$\begin{array}{c}1894 \text { senesi } \\
\text { Mayıs ayı so- } \\
\text { nuna kadar ya- } \\
\text { pılan harcama- } \\
\text { lar }\end{array}$} \\
\hline & Kuruş & $\begin{array}{l}\text { San- } \\
\text { tim }\end{array}$ & Kuruş & $\begin{array}{l}\text { San- } \\
\text { tim }\end{array}$ \\
\hline $\begin{array}{c}\text { Söz konusu binalara getirilecek suyun özel kanalı yapılan anlaşmaya mahsuben } \\
\text { bankadan }\end{array}$ & 80.000 & --- & --- & --- \\
\hline Osmanlı Bankası’ndan alınan yirmi beş adet çek parasına bankadan & 14 & --- & --- & --- \\
\hline Basılan biletlerin arkalarını mühürlemek için kazıttırılan mühür ücreti vezneden & 95 & --- & --- & --- \\
\hline $\begin{array}{c}\text { Basılan biletlerin arkalarını mühürlemek için çalıştırılan ciltçi yevmiyesiyle vila- } \\
\text { yetlere gönderilenlerin bağlama masraflarına vezneden }\end{array}$ & 718 & --- & --- & --- \\
\hline $\begin{array}{c}\text { Söz konusu binaların yerlerini belirlemek için gönderilen iki görevlinin harcırahla- } \\
\text { rına vezneden }\end{array}$ & 470 & 25 & --- & --- \\
\hline Söz konusu binaların çeşitli masraflarına vezneden & 950 & --- & --- & --- \\
\hline Söz konusu binaların temel atma anında kesilecek kurban masraflarına vezneden & 2500 & --- & --- & --- \\
\hline $\begin{array}{c}\text { Vilayetlerden posta ile ve poliçe gelen paraların hamaliye (taşıma) ve sairesine } \\
\text { vezneden }\end{array}$ & 184 & 25 & --- & --- \\
\hline Bankada bulunan tahsilât bakiyesi 4 Nisan 1893 & 1.678 .946 & 93 & --- & --- \\
\hline Müteahhid Vasilaki Efendi'ye Osmanlı Bankası'ndan &.--- & --- & 199.994 & --- \\
\hline Malatya yardımı olduğu daha sonra anlaşılıp geri verilen Osmanlı Bankası'ndan & --- & --- & 12.350 & --- \\
\hline Vilayetlerden gelen paraların taşıma parası vezneden & --- & --- & 343 & 42 \\
\hline Yemen Vilayeti'nden gelen paranın nakliye parası vezneden & --- & --- & 100 & --- \\
\hline TOPLAM & 1.763 .877 & 143 & 212.787 & 42 \\
\hline GENEL TOPLAM & 1.9 & 6.664 & 185 & antim \\
\hline
\end{tabular}

Kaynak: BOA, A.MKT. MHM 703-1/32-01

Darülaceze'nin kuruluş giderleri 1894 yılında aylar itibariyle tablolaştırılmıştır. Kuruluş giderleri olması sebebi ile giderlerin daha çok su kanalı yapılması, toplanan yardımların mühür ücretleri, havalesi, Müteahhide yapılan ödemeler gibi kalemlerden oluşmaktadır (BOA, A.MKT. MHM 703-1/32-01).

Tablo 4: 1894 Yılı Darülaceze Giderleri ( Haziran-Eylül Ayları) 1894 Senesi Darülaceze Giderleri ( Haziran-Eylül Ayları)

\begin{tabular}{|c|c|c|c|c|c|c|}
\hline \multicolumn{7}{|c|}{1894 Senesi Darülaceze Giderleri ( Haziran-Eylül Ayları) } \\
\hline \multirow[b]{2}{*}{ Gider kalemleri } & \multicolumn{2}{|c|}{ Haziran Ayı } & \multicolumn{2}{|c|}{ Ağustos Ayı } & \multicolumn{2}{|c|}{ Eylül Ayı } \\
\hline & Kuruş & $\begin{array}{c}\text { San- } \\
\text { tim }\end{array}$ & Kuruş & $\begin{array}{c}\text { San- } \\
\text { tim }\end{array}$ & $\begin{array}{l}\text { Ku- } \\
\text { ruş }\end{array}$ & $\begin{array}{l}\text { San- } \\
\text { tim }\end{array}$ \\
\hline Müteahhid Vasilaki Efendi Hazretleri'ne Osmanlı Bankası'ndan & 299.991 & & & & & \\
\hline $\begin{array}{l}\text { Darülaceze binalarının ve muayenesi için komisyon heyetinin } \\
\text { gidiş ve dönüş masrafları vezneden }\end{array}$ & 1.000 & --- & --- & --- & --- & --- \\
\hline Yemen Vilayeti'nden gelen paralar & 76 & --- & --- & --- & --- & --- \\
\hline Vasilaki Efendi'ye verilen bankadan & --- & --- & 149.986 & --- & --- & --- \\
\hline $\begin{array}{l}1894 \text { senesi Mayıs ayından bu yılın Temmuz ayı sonuna kadar } \\
\text { vilayetlerden gelen paranın taşıma ücreti ve sairesi }\end{array}$ & --- & --- & --- & --- & 439 & 20 \\
\hline Hudeyde Sancağı'ndan gelen paranın taşıma ücreti ve sairesi & --- & --- & --- & --- & 12 & --- \\
\hline TOPLAM & 301.067 & 0 & 149.986 & 0 & 451 & 20 \\
\hline GENEL TOPLAM & & & & 151.50 & uruş 2 & antim \\
\hline
\end{tabular}

Kaynak:BOA, A.MKT. MHM 703-1/32-01

1894 yılı Haziran -Eylül arası giderler ise Müteahhid Vasilaki Efendiye, Darülaceze binasının muayenesi için giderler, vilayetlerden gelen paralar ve taşıma ücretlerinden oluşmaktadır. 
Tablo 5: 1894 Yılı Darülaceze Giderleri (Ekim-Aralık Ayları)

\begin{tabular}{|c|c|c|c|c|c|c|}
\hline \multicolumn{7}{|c|}{1894 Senesi Darülaceze Giderleri Ekim -Aralık Ayları } \\
\hline \multirow[b]{2}{*}{ Gider kalemleri } & \multicolumn{2}{|c|}{$\begin{array}{c}\text { Ekim } \\
\text { Ayı }\end{array}$} & \multicolumn{2}{|c|}{$\begin{array}{c}\text { Kasım } \\
\text { Ayı }\end{array}$} & \multicolumn{2}{|c|}{$\begin{array}{c}\text { Aralık } \\
\text { Ayı }\end{array}$} \\
\hline & Kuruş & $\begin{array}{c}\text { San- } \\
\text { tim }\end{array}$ & Kuruş & $\begin{array}{c}\text { San- } \\
\text { tim }\end{array}$ & Kuruş & $\begin{array}{l}\text { San- } \\
\text { tim }\end{array}$ \\
\hline Müteahhit Vasilaki Efendi'ye verilen & 199.994 & --- & --- & --- & --- & --- \\
\hline $\begin{array}{l}\text { Şişli'den Darülaceze'ye ve oradan Okmeydanı'na kadar inşa } \\
\text { olunacak yolun müteahhidi Mehmed Efendi'ye verilen. } \\
\text { Vezneden }\end{array}$ & --- & --- & 10.650 & --- & --- & --- \\
\hline Yol müteahhidi Mehmed Efendi'ye & --- & --- & --- & --- & 11.800 & --- \\
\hline $\begin{array}{l}1894 \text { senesi Ağustos'undan Eylül sonuna kadar vilayetlerden } \\
\text { gelen paraların taşıma ücreti }\end{array}$ & --- & --- & --- & --- & 117 & --- \\
\hline Müteahhid Vasilaki Efendi'ye & --- & --- & --- & --- & 149.986 & --- \\
\hline TOPLAM & 199.994 & 0 & 10.650 & 0 & 161.903 & 80 \\
\hline GENEL TOPLAM & & & & & 47kuruş 8 & santim \\
\hline
\end{tabular}

Kaynak:BOA, A.MKT. MHM 703-1/32-01

Ekim-Aralık ayları arasında ise Müteahhid Vasilaki Efendiye verilen para, Yol müteahhidi Mehmet Efendi'ye verilen para, Vilayetlerden gelen paranın taşıma ücretinden oluşmaktadır.

\section{Darülaceze'nin 1895 Yılı Giderleri}

1895 yılı giderleri ise yol müteahhidi Mehmed Efendiye verilen para, paralar taşıma ücretleri, Darülaceze inşaatının teftiş ve muayenesi için masraflar, Darülaceze yollarına döşenecek ağaçlar için ödenecek ücret, Müteahhid Vasilaki Efendiye verilen paralar, Darülaceze inşaatı için harcanan suyun ücretinden oluşmaktadır.

Tablo 6: 1895 Yılı Darülaceze Giderleri (Ocak-Mayıs Ayları)

\begin{tabular}{|c|c|c|c|c|c|c|}
\hline \multicolumn{7}{|c|}{1895 Senesi Darülaceze Giderleri ( Ocak-Mayıs) } \\
\hline & \multicolumn{2}{|c|}{ Ocak Ayı } & \multicolumn{2}{|c|}{ Şubat Ayı } & \multicolumn{2}{|c|}{ Mayıs Ayı } \\
\hline Gider kalemleri & Kuruş & $\begin{array}{c}\text { San- } \\
\text { tim }\end{array}$ & Kuruş & $\begin{array}{c}\text { San- } \\
\text { tim }\end{array}$ & Kuruş & $\begin{array}{l}\text { San- } \\
\text { tim }\end{array}$ \\
\hline Yol müteahhidi Mehmed Efendi'ye verilen & 21.800 & --- & --- & --- & --- & --- \\
\hline $\begin{array}{l}1895 \text { senesi Ocak ayı başından Mayıs ayı sonuna kadar } \\
\text { vilayetler ve sair yerlerden gelen paraların taşıma üc- } \\
\text { reti ve sâiresi. Vezneden }\end{array}$ & 202 & 35 & --- & --- & --- & --- \\
\hline $\begin{array}{l}\text { Yemen Vilayeti'yle Hudeyde Sancağı'ndan gelen para- } \\
\text { ların taşıma ücreti ve sâiresi. Vezneden }\end{array}$ & 11 & 92 & --- & --- & --- & --- \\
\hline $\begin{array}{l}\text { Darülaceze inşaatının teftiş ve muayenesi ve saire } \\
\text { masrafları }\end{array}$ & --- & --- & 1.425 & --- & --- & --- \\
\hline $\begin{array}{l}\text { Darülaceze yollarına döşenecek çınar ağaçlarının ücre- } \\
\text { tine mahsuben Mösyö Koh'a verilen: } 2.968 \text { kuruş } 75 \\
\text { santim vezneden }\end{array}$ & --- & --- & 9.100 & 60 & --- & --- \\
\hline $\begin{array}{c}\text { Darülaceze yol müteahhidine } 1.9650 \text { lira yol masrafına } \\
\text { mahsuben verilen } \\
6.131 \text { kuruş } 85 \text { santim Bankadan } \\
9.000 \text { kuruş } 60 \text { santim }\end{array}$ & --- & --- & 29.950 & --- & --- & --- \\
\hline 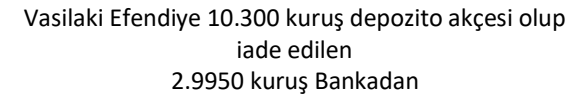 & --- & --- & $\begin{array}{c}19.988 \\
+ \\
499.985\end{array}$ & --- & --- & --- \\
\hline Yol müteahhidi Mehmet Efendi'ye & --- & --- & --- & --- & $\begin{array}{c}10.000+ \\
15.000+ \\
20.000\end{array}$ & --- \\
\hline $\begin{array}{c}\text { Darülaceze İnşaatının harcanan suyun ücreti olarak su } \\
\text { şirketine }\end{array}$ & --- & --- & --- & ---- & 4.239 & --- \\
\hline Vasilaki Efendi'ye & --- & --- & --- & --- & 299.985 & --- \\
\hline TOPLAM & 22.013 & 127 & 560.448 & 60 & 349.224 & 0 \\
\hline GENEL TOPLAM & & & & & 685 kuruş 1 & antim \\
\hline
\end{tabular}

Kaynak: BOA, A.MKT. MHM.703-1/34-02 
Tablo 7: 1895 Yılı Darülaceze Giderleri ( Haziran-Ağustos Ayları) 1895 Senesi Darülaceze Giderleri ( Haziran- Ağustos Ayı Giderleri)

\begin{tabular}{|c|c|c|c|c|c|c|}
\hline \multirow[b]{2}{*}{ Gider kalemleri } & \multicolumn{2}{|c|}{$\begin{array}{c}\text { Haziran } \\
\text { Ayı } \\
\end{array}$} & \multicolumn{2}{|c|}{$\begin{array}{c}\text { Ağustos } \\
\text { Ayı }\end{array}$} & \multicolumn{2}{|c|}{$\begin{array}{c}\text { Eylül } \\
\text { Ayı } \\
\end{array}$} \\
\hline & Kuruş & $\begin{array}{c}\text { San- } \\
\text { tim }\end{array}$ & Kuruş & $\begin{array}{l}\text { San- } \\
\text { tim }\end{array}$ & Kuruş & $\begin{array}{l}\text { San- } \\
\text { tim }\end{array}$ \\
\hline Müteahhid Vasilaki Efendi'ye, bankadan & 499.985 & --- & --- & --- & --- & --- \\
\hline Mösyö Dalmas'a, bankadan & 8.000 & --- & --- & --- & --- & --- \\
\hline Yol müteahhidi Mehmet Efendi'ye bankadan & 8.250 & --- & --- & --- & --- & --- \\
\hline $\begin{array}{c}\text { Bingazi Sancağı'ndan gelen paraların taşıma ücreti, } \\
\text { vezneden }\end{array}$ & 13 & --- & --- & --- & --- & --- \\
\hline Yol müteahhidi Mehmet Efendi'ye & --- & --- & 10.640 & --- & --- & --- \\
\hline Vasilaki Efendi'ye & --- & --- & 499.985 & --- & --- & --- \\
\hline Sifon müteahhidi Mösyö Almas'a & --- & --- & 5.000 & --- & --- & --- \\
\hline $\begin{array}{l}1894 \text { senesi Ekim ayı başından } 1895 \text { senesi Temmuzu } \\
\text { ayı sonuna kadar vilayetlerden gelen paraların taşıma } \\
\text { ve sairesine }\end{array}$ & --- & --- & 231 & 10 & --- & --- \\
\hline Hudeyde Sancağı'ndan gelen paranın vapur navlunu & --- & --- & 17 & --- & --- & --- \\
\hline Bingazi Sancağı'ndan gelen paranın vapur navlunu & --- & --- & 8 & --- & --- & --- \\
\hline Müteahhit Vasilaki Efendi'ye, bankadan & --- & --- & --- & --- & 199.994 & --- \\
\hline $\begin{array}{c}1895 \text { senesi Temmuz ayından } 1896 \text { senesi Eylül ayı } \\
\text { sonuna kadar satın alınan kırtasiye ücreti }\end{array}$ & --- & --- & --- & --- & 90 & 50 \\
\hline TOPLAM & 516.248 & 0 & 515.881 & 10 & 200.084 & 50 \\
\hline GENEL TOPLAM & & & & 1.232. & 3 kuruş 60 & antim \\
\hline
\end{tabular}

Kaynak:BOA, A.MKT. MHM.703-1/34-02

1895 senesi Haziran- Ağustos ayı giderleri ise şu şekildedir: Müteahhid Vasilaki Efendiye verilen para, Mösyö Dalmas'a verilen para, Yol Müteahhidi Mehmed Efendiye verilen para, Müteahhid Vasilaki Efendiye verilen para, Sifon müteahhidi Mösyö Almasa verilen para ve 1895-1896 Temmuz-Eylül ayları arası satın alına kırtasiye ücretinden oluşmaktadır(BOA, A.MKT. MHM.7031/34-02, BOA, A.MKT. MHM 703-1/46-01).

Tablo 8: 1894 ve 1895 Yılları Darülaceze Gelir-Gider Dengesi 1894 ve 1895 Yılları Gelir Gider Dengesi

Kaynak: BOA, A.MKT. MHM 703-1/46-01

\section{Darülaceze Yönetimi}

1895 yılında yayınlanan Darülaceze içtüzüğüne göre, Darülaceze1 müdür, 1 müdür yardımCISı, 1 muhasebeci 1 sandık emini, 1 başkâtip, 1 kâtip, 1 imam, 1 müezzin,3 papaz, 1 haham, Müslüman ve gayrimüslim çocukları okutmak için 2 öğretmen, çeşitli sanatları öğretmek için de ustalar, 1 vekilharç, 1 vekilharç yamağı bulunmaktaydı. Darülaceze Müdüriyeti tarafından bir muhasebeci bir müdür muavini ve başhekimden oluşan bir komisyon tarafından idari işler yürütülürdü(Koçu, 1974:59).

Darülaceze kuruluşundan itibaren Dâhiliye Nezareti'ne bağlı olarak faaliyete geçmişti. Darülaceze Nizamname-i Dâhilîsine göre Darülaceze iç yönetmeliğe bağlı olarak yönetilecekti. Kurum çalışanlarının atanması, aceze kabulü ve acezenin eğitim ve terbiyelerinin temini, uygulanacak cezalar Darülaceze nizamnamesi tarafından belirlenecekti. Darülaceze Nizamnamesi'ne göre, Darülaceze yönetimi müdüre, genel işleri ise özel olarak tahsis edilecek bir heyete verilmişti. Bu 
heyet fahri olarak çalışacağı planlanmış olu heyetin başkanı şehremaneti memurlarından seçilecek üyeleri ise Bab-i Fetva, Evkaf ve Zaptiye Nezaretleri memurlarından belirtilenlerden oluşacaktı. Darülaceze resmi olarak açıldıktan sonra yönetim kademeleri oluşturulmuştu. 1896 yıIında müdürlüğüne Umur-ı Tıbbiye -i Mülkiye Muhasebe muavini Selahaddin Bey atanmıştı. Darülaceze yönetimi müdüre verilirken iç işleri ise Fahri komisyon olan üyeleri farklı milletlerden olan Muhtelit Komisyona verilmişti. Darülaceze'nin Illk müdürü Selahaddin Beydi. İkinci Müdürü ise Ziya Bey idi. Darülaceze'nin açılışından 1908 yılına kadar kurumun başına müdür atanan kişilerin görev sürelerinin çok kısa olduğu dikkat çekmektedir. illk müdür üç sene görev yapmışken ikinci müdür Ziya Bey sadece bir yıl görev yapmıştır. Yolsuzlukların ortaya çıkması sebebi ile sık sık müdür konumundaki kişilerin görevden alındığını görüyoruz. 1901 yılında müdürlüğe Ankara Maarif Müdürü atanmışken kurum istenildiği gibi idare edilememesi sebebiyle1906 yılında müdürlüğe Fahreddin Bey atanmıştı. Yolsuzluk olaylarının devam etmesi üzerine1909 yılında Fahreddin Bey görevden alınmış ve Darülaceze yönetimi 1909 yılında Şehremanetine bağlanmıştır(Özen, 2001:22-23).

\section{Darülaceze 'de Bulunan Birimler: Irza'hane( Çocuk Yuvası)}

Darülaceze yaşı, yardıma muhtaç, kimsesiz, sakatların alınması dışında zaman içerisinde yardıma muhtaç bebek ve çocuklara da hizmet edilmeye başlanmıştır. Darülaceze'ye ırza'hane adı verilen bir çocuk yuvası açılmıştı. Bu kurum anne ve babası olmayan, sütninesi bulunmayan çocuklar sokaklara bırakılmış ve yaşı sebebi ile süte ihtiyacı olan çocuklar için bir sığınma yeri açılmış oldu. Bu çocuklara verilen sığınma hakkı ve beslenme büyük önem taşımaktadır. Zira çocuk ölümlerinin en önemli sebeplerinden biri yeterli derecede besin alamamalarıdır. Bu çocuklarına beslenme ve giyim konusunda Viyana'dan özel olarak getirilen mikrop tutmayan boyalarla duvarlar boyanmış ve dadılar getirtilmiştir. Yine bu çocukların beslenmeleri amacıyla müdür tarafından kontrol edilen Darülaceze ahırında beslenen ineklerden sağılan sütler sterilize edilerek emzik ve kaşık ile içirilmektedir. Bu özenli çabalar sonucunda çocukların gezinti arabaları, mekanik sandalyeleri ve düzenli banyoları ve beslenmeye verilen önem sayesinden çocuk ölümlerinin azaldığı görülmektedir (Özkaya, 2014:127). Çocuk yuvası 0-4 yaş arası çocuklar alınıyordu( Demirel,2011-119).Dört yaşını dolduran çocuklar ise yetimhaneye gönderiliyordu. Dadılar, Darülaceze çocuk yuvası yazılı kolluklar takmaktaydı (Yıldırım,1996:162).

Çocuk yuvasında bulunan çocuklar her gün tartılarak kayıtları tutuluyordu. Çocukların her gün tartılması Darülaceze çocuk doktoru Kadri Raşit Anday tarafından uygulamaya geçirilmişti. Çocuk yuvasında bir buçuk iki yaşına gelen bebekler sütten kesilerek bir başka koğuş ayrılırdı.1903 yılında yatakhanelerden başka yemekhane çamaşırhane mutfak depo dört yataklı küçük bir hastane bulunuyordu. 1903 yılında kreşte 33 çocuk bulunuyor bu çocukların 17si süt çocuğu 16sı ise sütten kesilmiş bebeklerdi. 1906 yılında ise aynı kreşte 38 bebek yetimhanede ise30 çocuk bulunuyordu (Yıldırım,1996:163).

\section{Darülaceze illkokulu}

Darülaceze'de yaşayan çocuklar intiyaçları karşılanmakta olup ancak geleceklerini bir meslek öğrenerek teminat altına almaları gerektiğinden Darülaceze bünyesinde bir eğitim kurumu kurulması hâsıl olmuştu (Özkaya, 2014:189).

7 Eylül 1886 tarihinde Darülaceze dâhilinde hayır kurumunda çocuklara dini inanışları ve basit bilgilerin öğretilmesi ayrıca çalışacakları sanayihaneler kurulması için karar alınmıştı(Yıldırım,1996:167). Bu amaçla sıbyan, ihtiyat ve iptidai, özel kısım olmak üzere dört şubeden oluşan bir okul açılmıştı. Bu okulun programı ihtiyaca göre, üç öğretmen bir öğretmen yardımcısı, üç 
mübaşir, kızlara ayrılan bölüm ise, bir bayan öğretmen ve bir bayan mübaşir ile yönetilmekteydi (Özkaya, 2014:189).

Darülaceze'de eğitim süreçlerinin iyi devam etmesi, imalathanelerin gelişmesi üzerine okulda eğitimde müzik derslerinin de verilmesi uygun görülmüştür. Darülaceze'de bir mızıka takımı kurulması gereği dönemin Maliye Nazırı Memduh Bey tarafından düşünülmüştür. Darülaceze'de bulunan çocuklardan bir bando takımı kurulması gerektiğinden bahsedilmiştir. Bunun yanında ünlü müzik aletleri sipariş edilmiştir. Memduh Paşa bir sohbet sırasında Aşık Razi' den Darülaceze Marşı yazmasını istedi (Koçu,1974:10).

\section{Sonuç}

Osmanlı Devleti fakir, fukaraya, güçsüze bakmayı kendine bir yükümlülük olarak görmüştür. 19. yüzyıl ile birlikte ülke koşulları siyasi, ekonomik ve sosyal olarak değişmiş ve zaman içerisinde Osmanlı Devleti'nin yoksullara yardım biçimi de şekil değiştirerek devam etmiştir. Sosyal yardım faaliyetleri III. Selim devrinde başlamış ve ilk olarak Rum ve Ermeni dilenci hastaların korunması amacı ile Kuruçeşme'de bir Tıp Okulu ve Darülaceze açılmıştı.

19. yüzyıla gelindiğinde ise sosyal hayata birçok alanda etki edecek modern bir yapılanma oluşmuştur. 19. yüzyıla kadar vakıf ve imaretler sosyal yardım işlevini görürken yeni kurumlara ihtiyaç duyulmuştur. II. Abdülhamid dönemine gelindiğinde ise sosyal yardım ve politika konusunda önemli adımlar atılmıştır. Geçim sıkıntısı çeken nüfus dilencilik yapmaya başlamıştır. Bu gelişmeler ışığında Osmanlı Devleti dilenciliği önlemek amacıyla Darülaceze'nin kurulmasına karar verilmiştir. Kurulma amacı sokaklarda kimsesiz çocuklar, sakat erkek ve kadınlar için dilenmeyi engellemek için açılmıştır.

Bu çalışmada ilk defa Darülaceze'nin inşa aşamasında olan gelirleri ve giderleri ayrıntılı olarak incelenmiştir. Kurum inşa edilirken Osmanlı Devleti'nin tüm vatandaşlarından hatta diğer dünya ülkelerinden yardım toplanmıştır. İnşaat için gelirler titizlikle düzenli bir şekilde toplanmıştır. Gelirlerin toplanması üç kalem altında gerçekleştirilmiş merkezi dairelerden gelen yardımlar, vilayetlerden gelen yardımlar, bazı kişiler tarafından nakden yardımlar olarak bölümlendirilmiştir. Merkezi dairelerden her ay düzenli bir şekilde yardım toplanmıştır. Ancak her ay aynı nezaretler düzenli bir şekilde devam etmemiştir. Vilayetlerden iste daha düzenli bir şekilde her ay aynı vilayetlerden yardım toplanmıştır. Ancak vilayetlerden gelen düzenli ödenmesinin sebebi düzenli bir şekilde bakanlıklar tarafından ödeme yapılması istenmiştir. Darülaceze'nin inşaatından toplumun her kesiminden bu kurumun açılması için mali yardımda bulunulmuştur. En küçük meblağdan en yüksek meblağa kadar herkes bu kurumun açılması için bir çaba göstermiştir. Aslında Darülaceze'nin kuruluşunda Osmanlı Devleti'nde toplum olarak sosyal yardımların bir kültür haline geldiğini ve yerleştiğini görüyoruz. 


\section{Eskişehir Osmangazi Üniversitesi IïB Dergisi}

\section{Kaynaklar}

Akyol, Esra Demirci (Temmuz-Aralık 2013), "Sultan II. Abdülhamid Döneminde Sosyal Politika Uygulamaları" Sosyal Politika Çalışmaları Dergisi, Yıl 13, S.31, :34-54.

Aytekin, Hakan (2006),1914-1924 Yılları Arasında Korunmaya Muhtaç Çocuklar ve Eğitimleri, Marmara Üniversitesi Türkiyat Araştırmaları Enstitüsü, Basılmamış Yüksek Lisans Tezi.

Demirel, Fatmagül (2011)Sultan II. Abdülhamid'in Mirası, İstanbul'da Kamu Binaları, İstanbul: İstanbul Ticaret Odası Yayınları, Yayın No 2011-11.

Düstur (Birinci Tertip) 1289-1322 İstanbul; Ankara: Başvekâlet Neşriyat ve Müdevvenat Dairesi Müdürlüğü.

Nuhoğlu, Hidayet (1993),'Darülaceze', Diyanet İslam Ansiklopedisi, Ankara: Türkiye Diyanet Vakfı, C.8.

Şenyurt, Oya (Spring 2010), II. Abdülhamit Döneminde İki Ünlü Saray Mimarının Siyasi İlişkileri, Uluslararası Sosyal Araştırmalar Dergisi, Vol. 3,No.11:540-560.

Yıldırım, Nuran (1996), İstanbul Darülaceze Müessesi Tarihi, Darülaceze Yayınları.

Birol, Nurettin (2017),II. Abdülhamid Dönemi Hayır kurumlarından Darülaceze'nin Yapımı ve Halil Rıfat Paşa'nın Çalışmaları, Akra Kültür Sanat ve Edebiyat Dergisi, C.5,S.13:33-53.

Özbek, Nadir (2002), Osmanlı İmparatorluğunda Sosyal Devlet Siyaset, iktidar ve Meşruiyet (1876-1914), İstanbul: İletişim Yayınları.

Özkaya, Nevzat (2014),Sultan II. Abdülhamid Han'ın Hayır Kurumlarından Darülaceze, Aile ve Sosyal Politikalar Bakanlığı.

Özen, İmdat (2001), II. Meşrutiyete Kadar Islahhaneler ve Darülaceze, Ankara Üniversitesi SBE, Yayımlanmamış Yüksek Lisans Tezi.

Koçu, Reşat Ekrem (1974),Darülaceze(1895-1974), İstanbul: Darülaceze Yardım Derneği.

Küçük, Cevdet(1994),Düyun-u Umumiye, Türkiye Diyanet Vakfı İslam ansiklopedisi: Dümetülcendel-Elbise. -- Ankara: Türkiye Diyanet Vakfı, 10. c.

Öztürk, Said (2008), Osmanlı Devletinde Dilenciliğin Önlenmesi, Bir Kent Sorunu Dilencilik Sorunlar ve Çözüm Yolları Sempozyumu, İBB Zabıta Daire Başkanlığı, İstanbul, 2008, ss. 109-123.

Öztürk, Said (2019),"Osmanlı Su Yapılarında Vakıfların Rolü”, Vakıflar Dergisi 80. Yıl Özel Sayısı, T.C. Vakıflar Genel Müdürlüğü, Sayı 80, ss. 135-157.

Özbek, Nadir (2009), “Osmanlı İmparatorluğunda Dilencilere Yönelik Devlet Politikaları ve Kamusal Söylemin Değişimi, Bir Kent Sorunu Dilencilik Sorunlar ve Çözüm Yolları”,'̇̇stanbul: İstanbul Büyükşehir Belediyesi Zabıta Daire Başkanlığı,17-44.

Tabakoğlu, Ahmet(2014), Türkiye İktisat Tarihi, İstanbul: Dergâh Yayınları.

Tabakoğlu, Ahmet,(2013), İslam İktisadına Giriş, İstanbul: Dergâh Yayınları

Tabakoğlu, Ahmet, Sultan II. Abdülhamid Dönemi İktisadi Yapı, Devr-i Hamid: Sultan II. Abdülhamid. / hazırlayanlar Mehmet Metin Hülagü, Şakir Batmaz, Gülbadi Alan. -- Kayseri: Erciyes Üniversitesi, 2011.

Tabakoğlu, Ahmet, Karataşer, Büşra (2019), “ Değişim ve Dönüşüm Perspektifinden Osmanlı Iktisat Kurumlarının İktisadi Temelleri, Prof. Dr. Sabri Orman'a Armağan Değişim ve Dönüşüm Perspektifinden İktisadi Bakış, Bursa:Ekin Kitabevi.

Turgut, Bahattin (2018), İslam Medeniyetinde Vakfiye: Hz. Ömer Örneği, i̇lahiyat Tetkikleri Dergisi, Aralık,

Wensinck, A.S,(1936),Concordance et Indices de la Tradition Musulmane(el- Mu'cemu'l-müfehres li-elfazi'I-hadis'n-nebevi), Leiden .

Yazıcı, Nesim (2007), Osmanlılarda Yetimlerin Korunması Üzerine Bazı Değerlendirmeler, Ankara Üniversitesi İlahiyat Fakültesi Dergisi, S.1:1-46.

\section{Başbakanlık Osmanlı Arşivi Kaynakları}

BOA, A.MKT. MHM 703-1/6-2

BOA, A.MKT. MHM 703-1/8-1

BOA, A.MKT. MHM 703-1/8-2

BOA, A.MKT. MHM 703-1/34-2

BOA, A.MKT. MHM 703-1/36-2 
BOA, A.MKT. MHM 703-1/40-01 BOA, A.MKT. MHM 703-1-42-01 BOA, A.MKT. MHM 703-1-44-01 BOA, A.MKT. MHM 703-1-46-01 BOA, A.MKT. MHM 703-1/10-02 BOA, A.MKT. MHM 703-1/18-01 BOA, A.MKT. MHM 703-1/16-01 BOA, A.MKT. MHM 703-1/24-02 BOA, A.MKT. MHM 703-1/10-02 BOA, A.MKT. MHM 703-1/26-01 BOA, A.MKT. MHM 703-1/28-01 BOA, A.MKT. MHM 703-1/30-01 BOA, A.MKT. MHM 703-1/32-01 BOA, A.MKT. MHM.703-1/34-02 BOA, A.MKT. MHM 703-1/36-01 BOA, A.MKT. MHM 703-1/38-01 


\section{Extended Summary}

\section{An Evaluatıon on Establıshment Income Expenses of Darülaceze}

In the 19th century, political, military and cultural changes took place worldwide. The Ottomans kept up with this change of order and the social assistance applications that were already in progress in the society have accelerated. In the period of Abdulhamid II, modernization activities also showed itself in the field of social assistance. This article will focus on the establishment income expenses of Darülaceze, a social assistance institution. This assistance institution, which was established differently from the classical Ottoman assistance institutions, should be placed on a ground in the context of modernization / innovation. Darülaceze, founded in the period of Sultan Abdülhamid II as a social assistance institution in a modern sense, appears to have emerged with the aim of achieving a social and standard level. The Ottoman State wanted to make the issue of social assistance more standardized as a requirement of the modern state. Based on this, we will examine which individuals or institutions provided financial support in the establishment of Darülaceze, the reasons of these supports and in what fields the institution has expenses. With this article, it is aimed to reach the reasons behind the implementation of an important institution such as Darülaceze in a short time.

In the Ottoman State social services were carried out by the foundations until the 19th century. In the Islamic world it is accepted that the first foundation was founded by $\mathrm{Hz}$. Muhammed in 625. The foundation system is the third sub-element of the financial system as the institution that carries out the country's education, health and social assistance, religious and public works investments and is the basic institution of social security. Foundations are the basis of social service institutions in Islam. In the Islamic states, meanwhile, in the Seljuks and Ottomans consumer's surplus, which could not be directed towards luxury consumption, turned towards foundations and consisted a widespread fixed capital that increased social welfare. The base of the foundation is to remove a property from the individual ownership area as being the property of Allah and to offer it to the benefit of the people. It means that some services are financed (Tabakoğlu, 2016: 136).

The 19th century has been an unstable period in the world. Due to the wars and the movements of nationalism that started in the countries, migrations that took place caused the formation of states consisting of nations in the world. The migrating segment are the sick, the old and people who in need. For this reason, begging in society has increased, and problems reflected to the press have also occurred in the Ottoman state. The negative consequences that emerged after the 1877-1878 Ottoman-Russian war caused economic and political crises. Due to the war, there was a significant migration from Rumelia Region to Istanbul. Due to the Great War, nearly four hundred thousand people immigrated to Istanbul. An important part of the immigrant population consisted of homeless, disabled, sick people (Birol, 2017: 34).

The sources of begging in the Ottoman State have emerged as poverty, congenital and subsequent disability, disability, inadequate employment opportunities, difficulties caused by immigration due to wars and other reasons, lack of livelihood due to famine, thirst and disaster in their regions.(Öztürk,2008:110-111).

The Ottoman State made an impact on social life in many fields with the nineteenth century. Compared to the previous periods, with the development of modern technology, it caused a new bureaucratic state to be formed (Özbek, 2002: 47-48). With this idea in trouble in the 19th century, we see that while the intervention field of the state was expanding, on the one hand, the social area was formed. The issues of meeting the needs, ensuring the welfare and ensuring the happiness of the society were on the agenda of the state. The fact of ensuring the welfare and security of the society has made the State a modern state. In the Ottoman state, assistance to the poor was provided in cases such as the family's inability to provide a living and health problems.

It was thought that thoughts that played an active role in the announcement of Tanzimat and reforms done would begin with the army and spread to other areas. The Ottoman Empire was tried to be modernized with the ascending of II. Abdulhamid's throne and modern and traditional applications. The concept of social state was wanted to be created within the Ottoman country by following the modernization movements in Europe closely. While only the rich were benefiting from the increasing wealth in the world, it was seen that the poor lived in even worse and difficult conditions. (Akyol, 2013: 35).

During the reign of Abdulhamid II, important steps were taken regarding social assistance and policy. Schools opened for the deaf and dumb, the insurance fund created for the victims of work accident, and the social assistance system for those living in the Ottoman Empire was tried to be established. The aim of Abdulhamid II was to realize the social welfare programs by the state and to transform them into modern society. The first application in terms of social assistance during the reign of Abdulhamid II was Atiyye-i Seniyye. (Akyol, 2013: 35-40). Atiyye-i Seniyye is to donate money to the public in need. An allocation was made for Atiyye-i Seniyye in the Ottoman budgets.Before the Tanzimat period, Atiyye-i Seniyye expenditures were mostly made by the private accounts of the sultans, from Ceyb-i Humayen and later, these were met by the allowance allocated for the sultan and palace called Tahsisat-ı Seniyye. (Özbek, 2002: 125-126). 
Darülaceze was established in order to protect those who are orphans and needy in the society (Öztürk, 2008: 117). According to the first article of the Darülaceze Order, the Darülaceze was established directly under the Ministry of Internal Affairs and as an independent budget. The Darülaceze consisted of four sections: zükur, İnas, kids branch and Irza'hane. Only those who were born or settled in Dersaadet, those who are unable to do business and who do not have enough goods to live on, and those who are weak to work and needy will be accepted to Darülaceze. (Düstur, 1. tertip,1895:43-48).

In addition, in order to prevent increased begging in the streets, a regulation was issued on 29 January 1896 to ban begging. Following this regulation and the declaration of Second Constitution, public order and social order deterioration occurred, and events such as fraud, theft, and robbery tended to increase. When those coming from the provinces caused by these undesired problems gained weight, the Bum Regulations came into force. (Öztürk,2008:116) According to the ninth article of this Regulation, those who have the power to work but those who cannot work are accepted as bummer. Those who are power to work but do not work are arrested by the police and those who are from Istanbul or those who are from the province but settled in Istanbul will be released on bail by the police. Those from the provinces will be sent to their country. Those who are caught from begging a few times and are from Istanbul will be sent to the provinces (Düstur, 1895: 49). The founder of the Darülaceze is Sultan Abdülhamid II. With a will published on March 30,1890 , it was wanted to prevent begging children, disabled men and women begging on the streets and a place were requested to provide their education and care (Nuhoğlu, 1993:512). 
Eskişehir Osmangazi Üniversitesi IißBF Dergisi 